\title{
First record of the expansive harvestmen Dicranopalpus ramosus (Simon, 1909) (Arachnida: Opiliones) in Poland
}

\author{
Robert ROZWAŁKA ${ }^{1}$ and Tomasz RUTKOWSKI ${ }^{2}$ \\ ${ }^{1}$ Department of Zoology, Maria Curie-Sktodowska University, Akademicka 19, 20-033 Lublin, Poland; \\ e-mail: arachnologia@wp.pl \\ ${ }^{2}$ Natural History Collections, Faculty of Biology, Adam Mickiewicz University in Poznań, Umultowska 89, \\ 61-614 Poznań, Poland; e-mail: pardosa@gazeta.pl
}

\begin{abstract}
The harvestmen Dicranopalpus ramosus (Simon, 1909) (Arachnida: Opiliones) is reported from Poland for the first time. It was found in the Dąbrówka near Poznań (Wielkopolska Lowland), more than $400 \mathrm{~km}$ East of the nearest known localities of this species in Germany.
\end{abstract}

Key words: distribution, expansive species, new site

\section{INTRODUCTION}

The genus Dicranopalpus Doleschal, 1852 is represented in Europe by two species: $D$. ramosus (Simon, 1909) and D. caudatus Dresco, 1948. For many years D. caudatus was considered a synonym of D ramosus (Starega 1973, Martens 1978). Recently Wijnhoven and Prieto (2015) published the revalidation of taxonomical status of $D$. caudatus where the authors presented the accurate description of both species. According to them, D. caudatus is known from the Iberian Peninsula and two separate localities in southern England, while the range of D. ramosus extends from Morocco, northern coasts of Spain through France, England and Ireland, along the coastal zone of continental Europe reaching southern Sweden (Wijnhoven \& Prieto 2015).

The natural area of the Dicranopalpus ramosus, originally covered probably only the northwestern periphery of the Mediterranean Sea and the southwestern part of the Atlantic coast, e.g. Morocco, northern Spain and southwestern France (Starega 1973, Martens 1978, Hillard \& Sankey 1989, Hillard 2005). Findings in Britain, however, supposedly are the result of the introduction of this species in 1950s from continental Europe (Hillard 2005, Hillard \& Sankey 1989).

In the 90 s of the 20th century there was a rapid expansion of the Dicranopalpus ramosus in Western Europe. Soon, this harvestmen was discovered in the Netherlands (Cuppen 1994), Ireland (Cawley 1995), Belgium (Slosse 1995), Germany (Schmidt 2004), western and central France (Delfosse 2004, Delfosse \& Iorio 2009). Subsequent publications document the spreading of D. ramosus in the direction to north of Europe. Toft and Hansen (2011) report occurrence of this harvestman in Denmark, and Jonsson (2013) in southern Sweden (Fig. 1). Several publications indicate, that it became a very common species in a short period after its first record in Western Europe, what was documented in the reports from the Netherlands (Noordijk et. al. 2007, Wijnhoven 2009), Denmark (Toft \& Hansen 2011), Luxemburg (Muster \& Meyer 2014), Germany (Arachnologische Gesellschaft 2016) and Great Britain (Spider and Harvestman Recording Scheme 2016). Dicranopalpus ramosus is considered as an expansive species and according the current database of Arachnologische Gesellschaft (2016) the farthest east positions in Europe were distant by nearly $400 \mathrm{~km}$ from the western Polish border. 
Therefore, the discovery of the population of the species in Dąbrówka near Poznan is now the easternmost locality of Dicranopalpus ramosus in Europe.

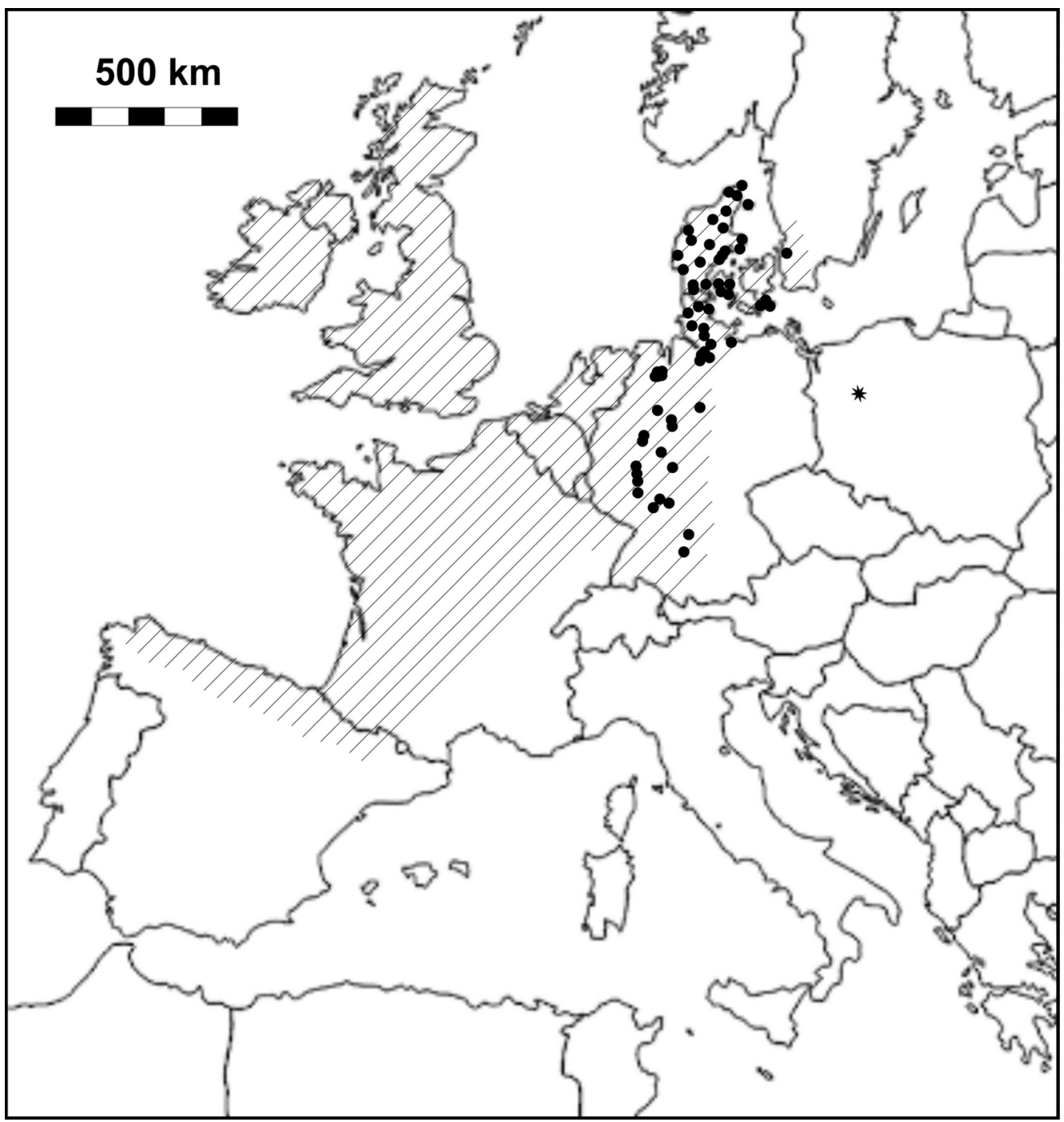

Fig. 1. Distribution of Dicranopalpus ramosus in Europe: asterisk - newly found position, dots - known data from the nearest location only, shaded area - likely continuous range.

\section{MATERIAL}

Location: Dąbrówka near Poznań [UTM XU 10], Lipowa St., geographical coordinates of the centre of the area: $52^{\circ} 22^{\prime} 58^{\prime \prime} \mathrm{N}, 16^{\circ} 44^{\prime} 44^{\prime \prime} \mathrm{E}$.

25 Sep $2014-2 \widehat{\jmath}, 1$ 우 (leg. T. Rutkowski); 8 Oct $2014-1 \hat{\jmath}, 1+$ and $1 \hat{\jmath}$ (obs.) (leg. \& obs. T. Rutkowski); 26 Oct $2014-2 \jmath^{\lambda}$ (obs. T. Rutkowski); 28 Oct $2014-1 \jmath^{\Uparrow} ; 29$ Oct 2014 - 4 ठิ઼ (obs. T. Rutkowski); 4 Nov 2014 - $1 \hat{\jmath}$ (obs. T. Rutkowski); 8 Dec $2014-2 \hat{\jmath}$ (obs. T. Rutkowski); 9 Nov $2014-1 q$ (doc. phot. M. Adamczewski, ver. T. Rutkowski); 26 Nov 
2014 - $q$ (leg. T. Rutkowski); 27 Nov 2014 - 1ð̊; (leg. T. Rutkowski); 9 Aug 2015 - 4 juv. (obs. T. Rutkowski); 19 Sep $2015-3$ juv. (obs. T. Rutkowski); 13 Oct $2015-4 \hat{\jmath} \widehat{\jmath}, 3 q q$ (obs. T. Rutkowski); 15 Oct $2015-2 \hat{\jmath} \widehat{o}$ and 3 exx. (obs.) (leg. \& obs. T. Rutkowski); 21 Oct 2015

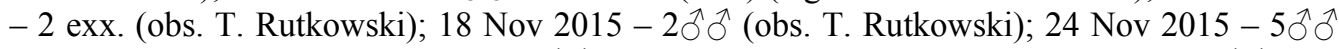

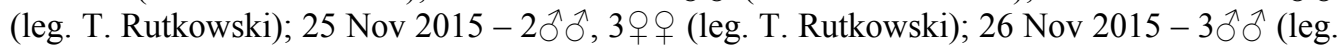
T. Rutkowski); 27 Nov $2015-1 \hat{\jmath}, 3$ 우 (leg. T. Rutkowski); 28 Nov $2015-2 \hat{\jmath} \widehat{\jmath}, 2$ 우 (leg. T. Rutkowski); 29 Nov 2015 - 4⿳亠े⿵冂, 1 + (leg. T. Rutkowski); 4 Dec 2015 - $1 \hat{\jmath}$ (obs. T.

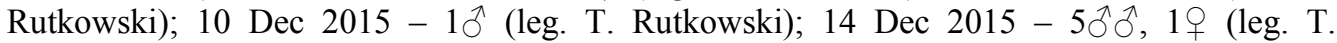

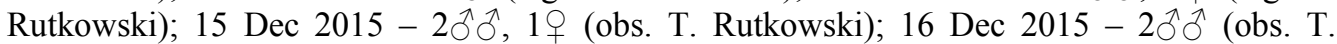

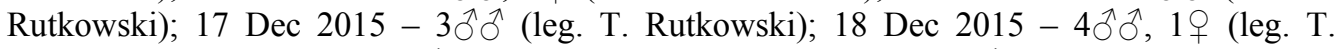
Rutkowski); 22 Dec 2015 - $1 \widehat{\jmath}$ (leg. T. Rutkowski); 27 Dec 2015 - 1ठ (leg. T. Rutkowski); 28 Dec $2015-2 \hat{\jmath}, 1$, (leg. T. Rutkowski); 30 Dec 2015 - 1ㅇ (leg. T. Rutkowski); 10 Dec $2015-2 \hat{\jmath} \hat{\jmath}, 3$ 우 (leg. T. Rutkowski); 8 Sep 2016 - 1 ex. (obs. T. Rutkowski); 10 Oct $2016-$ $1 \hat{\jmath}, 2$ 우 (obs. T. Rutkowski).

Comparative material: Netherland; province Utrecht, IJsselstein, Sagittapad Str., wall of building, 28 Aug - 3 Sep 2009 - 1ठ̋; leg. J. Stachowicz, det. et coll. R. Rozwałka.

\section{TAXONOMICAL IDENTIFICATION}

Dicranopalpus ramosus is easy to identify. As the only species occurring in Western and Central Europe, it has long finger-like apophyses on the patella of the pedipalps present in both sexes (Figs $2 \mathrm{~g}, \mathrm{~h} \& 3$ ). While resting, it takes a specific position, with all its legs spread sideways, unlike any other species of harvestman found in this part of the continent (Fig. 4).

Male (10 specimens): body ovoid, quite strongly flattened, length from 3.2 to $4.1 \mathrm{~mm}$ (3.7), covered with leathery cuticle (Fig. 2a). The color of the body variables, is a combination of different shades from yellow-brown to gray-brown in color. Cephalothoracic part lighter (yellowish-brown, dirty-yellowish, gray-yellowish) with a distinct darker (brown) lateral, trapezoidal or rectangular strip at the height of the eyes and darker areas of muscle insertions (Fig. 2a). Ocular tubercle unarmed, yellow-orange, away from the front edge approximately half of its length. Abdominal part gray-yellowish to gray-brown in color with a lighter stripe along the midline (Fig. 2a). Chelicerae honey in color, with numerous, darker tubercles tipped bristles on the dorsal surface of the basal segment and on the frontal surface of the second segment. Tips of pincers black-brown (Figs 2c, d). The length of the pedipalps approximately 4.4-5.1 $\mathrm{mm}\left(\mathrm{Fe}_{\mathrm{Pe}}-1.3\right)$ yellow-brown to dark-brown in color (Figs $2 \mathrm{~g} \& 3$ ), apical part of the foot distinctly darker. The femur of the pedipalp with short ventral process. Patella with long finger like apophysis on median side, reaching $2 / 3$ of tibia length (Figs $2 g \& 3$ ). The surface of the abdomen uniformly whitish. Coxa, genital operculum and abdominal sternites with quite a number of dark, short bristles. Coxa white to white-yellow, trochanters distinctly darker yellow-orange (brown-orange), other segments of the legs yellow-brown to brown, usually with slightly darker patella and lighter apical parts of femur and tibia. Tibia of all legs with pseudoarticulations, the number of which varies from 3 to 6 on $\mathrm{Ti}_{\mathrm{LI}}$, LIII, LIV, and 4-9 on $\mathrm{Ti}_{\text {LII }}$. Often the number of pseudoarticulations on tibia of left and right side differs. Length of $\widehat{\delta} \operatorname{legs}_{(\mathrm{Fe}+\mathrm{Pa}+\mathrm{Ti}+\mathrm{Mt}+\mathrm{Ta})}$ (in parentheses length of femur): $\mathrm{L}_{\mathrm{I}}-28.2$ (5.3); $\mathrm{L}_{\mathrm{II}}-51.0$ (9.3); $\mathrm{L}_{\mathrm{III}}-27.6$ (4.9); $\mathrm{L}_{\mathrm{IV}}-37.0$ (6.5). The penis pale-yellow, slightly sclerotized, around $1.3-1.5 \mathrm{~mm}$ in length. Truncus of the penis rod like, in apical part with tear shaped cavity (Fig. 2i, j), the glans slightly darker, oval, stylus fixed and short, with a small tuft of bristles on the bottom side (Fig. 2j). 

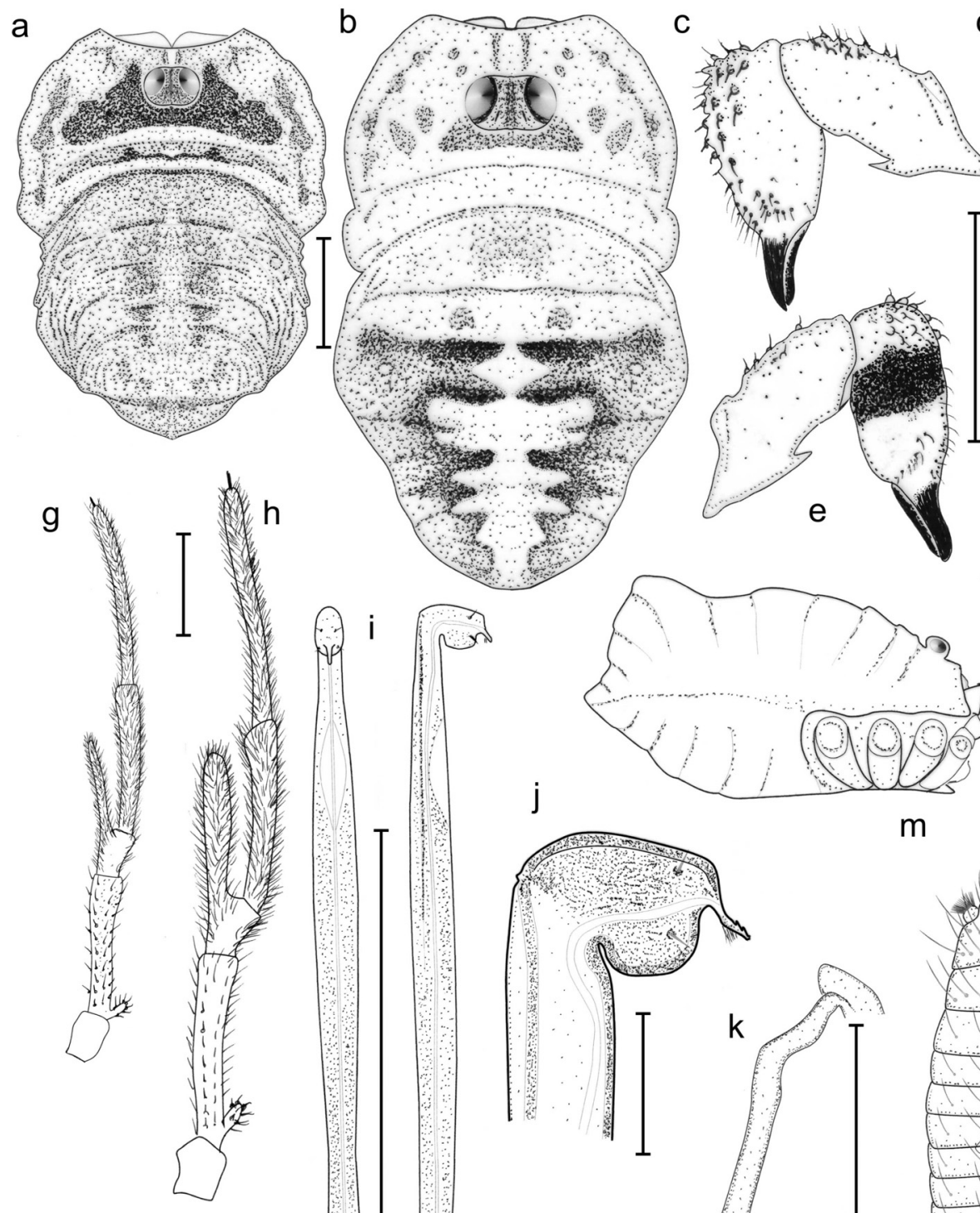

\section{d}
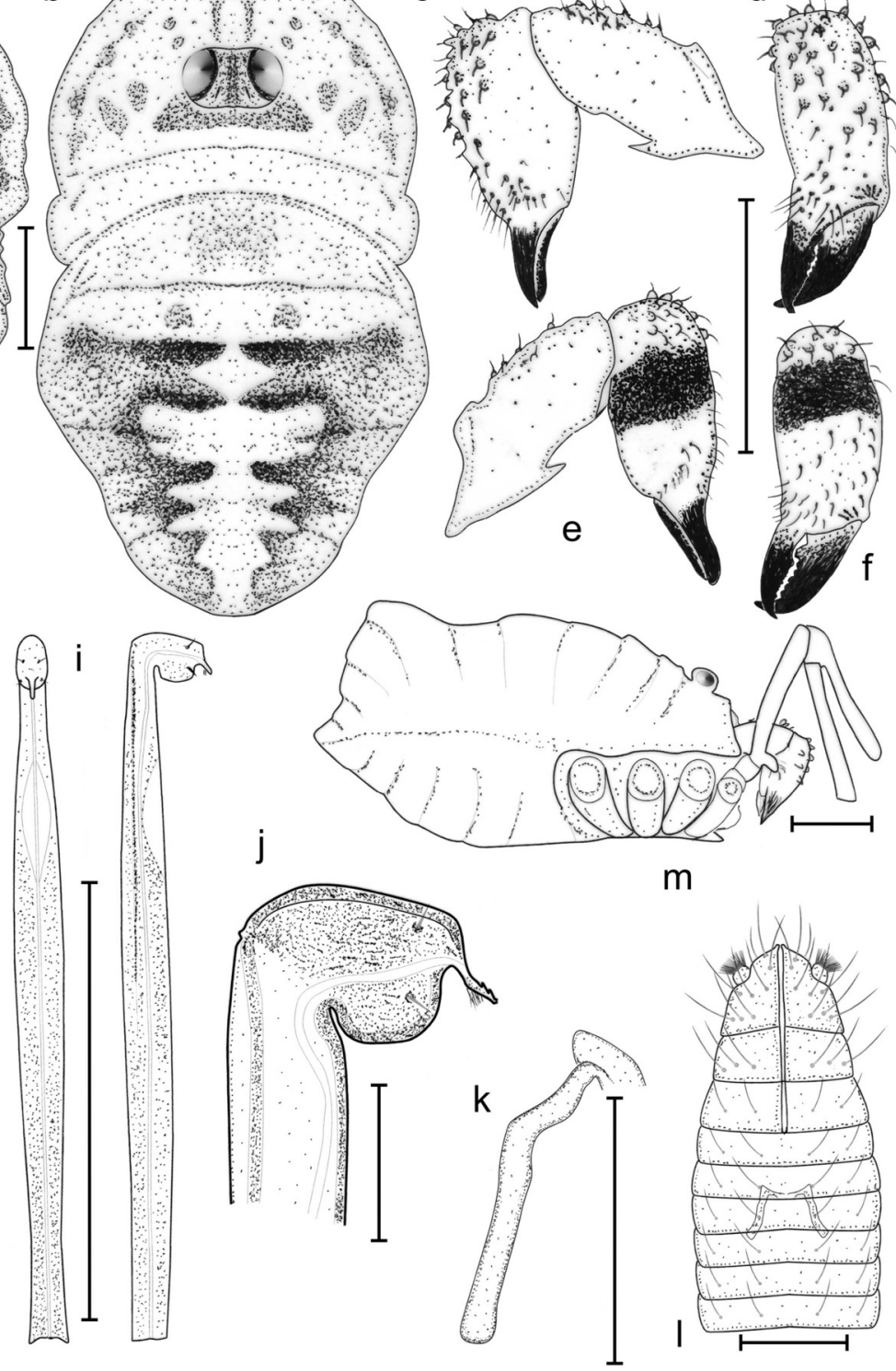

$\mathrm{m}$

Figs 2 (a-m). Dicranopalpus ramosus (Simon): a - male body, dorsal view; b - female body, dorsal view; $\mathrm{c}-$ male chelicerae, lateral view; $d$ - male chelicerae, frontal view; e - female chelicerae, lateral view; $f$ - female chelicerae, frontal view; $\mathrm{g}$ - male pedipalp, dorsal view; $\mathrm{h}$ - female pedipalp, dorsal view; $\mathrm{i}$ - penis, dorsal view (left) and lateral view (right); $\mathrm{j}$ - glans, lateral view: $\mathrm{k}$ - receptaculum seminis; 1 - ovipositor; $\mathrm{m}$ - female body, lateral view. Scale bars: $1.0 \mathrm{~mm}(\mathrm{a}-\mathrm{i}, \mathrm{m}), 0.2 \mathrm{~mm}(\mathrm{l}), 0.1 \mathrm{~mm}(\mathrm{j}-\mathrm{k})$.

Female (6 specimens): body elongated, length 4.9-6.0 $\mathrm{mm}$ (5.7) with distinct protuberance at the height of the 4-5 abdominal tergites (Figs 2b, m). Body coloration contrast, cephalothorax and first two tergites of the abdomen white-grayish other tergites distinctly darker (dark-gray). Along the midline of the abdomen extends brown framed, fingers like branched light spot (Fig. 2b). Ocular tubercle unarmed, yellow-orange, away from the front 
edge of the body approximately $2 / 3$ of its length. Muscle insertions darker, as is darker spot behind ocular tubercle (Fig. 2b). The basic color of chelicera yellowish, with clear brown-black band on the II segment (Figs 2e, f) and black tips of the pincers. Tubercles on I and II segment of chelicera present, but in fewer number than in male. The length of the pedipalp $4.9 \mathrm{~mm}\left(\mathrm{Fe}_{\mathrm{Pe}}\right.$ - 1.45). The femur of the pedipalp with short ventral process. Patella with long club like apophysis on median side, reaching almost to the end of the tibia (Fig. 2h). Trochanter and basal part of the femur whitish to white-yellow, apical part brownish, patella with the process dark brown, tibia light-brown with lighter apical part, foot gray-brown. Abdominal part of the body whitish, coxa slightly darker (yellow-whitish), trochanters yellow-orange. The femur and tibia white-yellowish or light-brown with distinctly darker ring in subapical part and with light (whitish) apical part. Patella distinctly darker than femur and tibia (brown), other segments of the legs yellow-brown. Tibia, alike the male with a variable number of pseudoarticulations: $3-$ 7 on $\mathrm{Ti}_{\mathrm{LI}}$, LIII, LIV, and $6-12$ on $\mathrm{Ti}_{\mathrm{LII}}{ }^{1}$. Length of $q$ legs (in parentheses length of femur): $\mathrm{L}_{\mathrm{I}}-$ 24.5 (4.3); $\mathrm{L}_{\mathrm{II}}-42.2$ (7.6); $\mathrm{L}_{\mathrm{III}}-23.4$ (4.2); $\mathrm{L}_{\mathrm{IV}}-32.6$ (5.6). Ovipositor length approximately $1.7-2.1 \mathrm{~mm}$, width $0.30-0.40 \mathrm{~mm}$, light brown, with $22-27$ segments. First $15-17$ segments with a fairly long bristles, gradually declining toward the base. Receptaculum seminis small, fingers like (Fig. 2k), weakly sclerotized, located mostly in II and III full segment (Fig. 21).
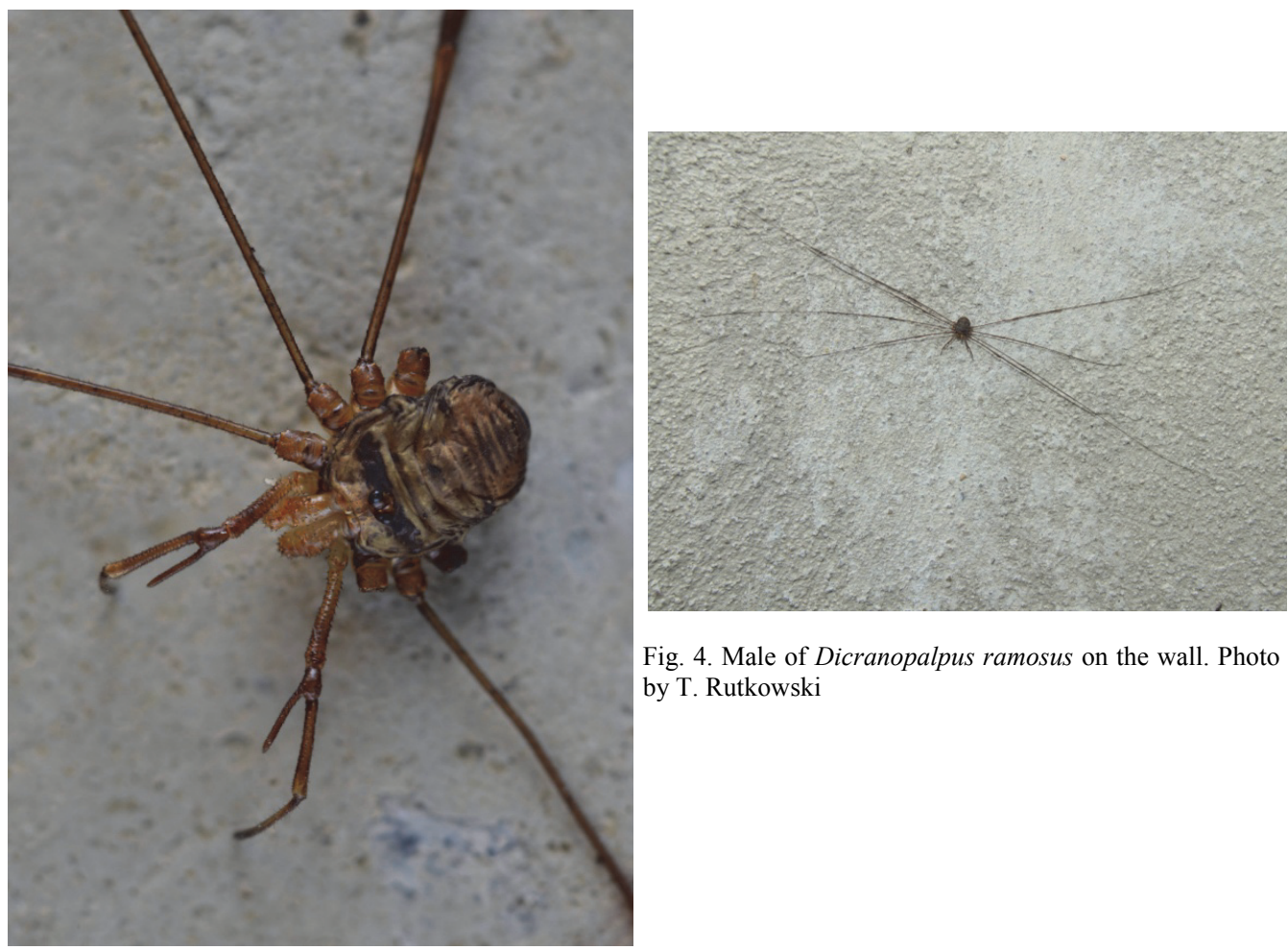

Fig. 4. Male of Dicranopalpus ramosus on the wall. Photo by T. Rutkowski

Fig. 3. Male of Dicranopalpus ramosus. Photo by M. Szewczyk.

\footnotetext{
${ }^{1}$ Wijnhoven (2013), in very detailed analysis performed on bigger number of specimens of $D$. ramosus also showed high variability in number of pseudoarticulations on tibia, but he did not mention the differences between right/left side.
} 


\section{DISCUSSION}

The newly discovered site in Poland is currently the most easterly known position of Dicranopalpus ramosus in Europe. The nearest noted locality of this harvestman are situated in central Germany (Lübeck - just about $440 \mathrm{~km}$ and Lehrte near Hanover (c.a. $470 \mathrm{~km}$ ) (Arachnologische Gesellschaft 2016, Fig. 1). The localization, where D. ramosus were found, is situated in a rapidly expanding suburban village belonging to the broader suburbs of Poznań. The harvestmen were collected and observed on a few hundred meter long wall surrounding a recently built residence, adjacent to the 19th-century park. Observations of many individuals over a period of several months suggest the existence of a sustainable population rather, than the effect of accidental introduction of a single individual, or a single deposit of eggs. However, this site of $D$. ramosus had to arise relatively recently, since searching for this species carried out in the immediate area and in several potential locations in western Poland gave a negative result. Presumably, the source of introduction of D. ramosus can be trees or ornamental plants brought from Western Europe, used to create a large garden.

In continental Europe Dicranopalpus ramosus is accounted for in mainly synanthropic environments, where it is found on the walls of buildings and on the trunks of trees, in parks, gardens, orchards, etc. (Hillard 2005, Noordijk et al. 2007, Wijnhoven 2009, Muster \& Mayer 2014). It was also noted from ruderal environments, semi-natural forests, etc. (Muster \& Mayer 2014). Data from the UK (Spider and Harvestman Recording Scheme 2016) point to the trunks, branches and leaves of trees and shrubs in natural environments as the main environment of occurrence of D. ramosus, and less likely, the data indicate the walls. It is possible that the advantage of synanthropic posts in continental Europe stems from the fact that these large, often resting in exposed places harvestmen are just easily noticeable there, in opposition to the individuals sitting on the trunks of trees, etc. The possibility of such a "methodical error" is mentioned by Noordijk et al. (2007). The second cause of the differences in the Dicranopalpus ramosus environmental preferences between Great Britain and continental Europe may be another phase of expansion. In Great Britain D. ramosus is present since 1950s of the 20th century, so it is now a long-established species and widely distributed (Spider and Harvestman Recording Scheme 2016). In the Benelux countries (Wijnhoven 2009, Muster \& Meyer 2014), Germany (Arachnologische Gesellschaft 2016), Denmark (Toft \& Hansen 2011), and Sweden (Jonsson 2013), D. ramosus is a relatively newcomer, therefore, its presence is limited mainly to anthropogenic environments, from where it is just starting to colonize the natural biotopes. The colonization scheme confirms the observations of the spread of other invasive harvestman species in Poland, e.g. Opilio canestrinii (Thorell) (Rozwałka \& Staręga 2012) or Odiellus spinosus (Rozwałka et al. 2013, 2014).

\section{ACKNOWLEDGEMENTS}

The authors thank Marian Szewczyk for taking and sharing photos of the Dicranopalpus ramosus and Maciej Adamczewski for providing photographic documentation.

\section{REFERENCES}

Arachnologische Gesellschaft 2016. Atlas of the European Arachnids. Version 1.6. Available at http://atlas.arages.de (10 Oct 2016).

CAWLEY M. 1995. Dicranopalpus ramosus (Simon) (Arachnida: Opiliones), new to Ireland. Irish Naturalist's Journal 25: 153.

CUPPEN J.G.M. 1994. Dicranopalpus ramosus, a new species of harvestman for the Netherlands (Opilionida: Phalangiidae). Entomologische Berichten 54: 176-178.

DELFOSSE E. 2004. Catalogue préliminaire des Opilions de France métropolitaine (Arachnida: Opiliones). Le bulletin de Phyllie 20: 34-58. 
Delfosse E. \& IORIO E. 2009. Contribution à la connaissance des Opilions de France métropolitaine (Arachnida: Opiliones). I. Bulletin de la Société Linnéenne de Bordeaux 37: 99-106.

HiLlyard P.D. 2005. Synopses of the British Fauna (New Series) No.4 (3rd Edition): Harvestmen. Field Studies Council, Shrewsbury, $167 \mathrm{pp}$.

Hillyard P.D. \& SANKey J.H.P. 1989 Harvestmen. Synopses of the British Fauna, new series. Linnean Society of London, 4: $119 \mathrm{pp}$.

JONSSON L.J. 2013. Grenlocke Dicranopalpus ramosus - en för Sverige ny art av lockespindel. Fauna och flora 108: $18-21$.

MARTENS J. 1978. Spinnentiere, Arachnida: Weberknechte, Opiliones. Die Tierwelt Deutschlands. Vol. 64. G. Fischer Verlag, Jena, 464 pp.

Muster C. \& MAYER M. 2014. Verbreitungsatlas der Weberknechte des Grossherzogtums Luxemburg. Ferrantia, 70: Musée national d'histoire naturelle, Luxembourg, 112 pp.

NOORDiJK J., WiJNHOVEN H. \& CUPPEN J.G.M. 2007. The distribution of the invasive harvestman Dicranopalpus ramosus in the Netherlands (Arachnida: Opiliones). Nederlandse Faunistische Mededelingen 26: 65-68.

ROZWAŁKA R. \& StARĘGA W. 2012. The invasive harvestmen Opilio canestrinii (Thorell, 1876) (Opiliones: Phalangiidae) in Poland. Fragmenta Faunistica 55: 161-168.

RozWAŁKA R., RutKowski T. \& SiENKIEWICZ P. 2013. New data on the occurrence of two invasive harvestmen species - Odiellus spinosus (Bosc) and Lacinius dentiger (C.L. Koch) in Poland. Fragmenta Faunistica 56: 47-54.

RozwaŁka R., RutKowski T. \& ORZEChOwski R. 2014. Nowe stanowiska ekspansywnego kosarza - Odiellus spinosus (Bosc, 1792) w Polsce. Przegląd Przyrodniczy 25: 54-58.

SCHMIDT C. 2004. Der Weberknecht Dicranopalpus ramosus (Simon, 1909) (Arachnida, Opiliones, Phalangiidae) neu fur Deutschland. Mitteilungen der Arbeitsgemeinschaft der Westfalischen Entomologen 20: 1-12.

SIMON E. 1909. Étude sur les Arachnides recueillis au Maroc par M. Martínez de la Escalera en 1907. Memorias de la Real Sociedad Española de Historia Natural 6: 5-43.

Slosse W. 1995. Dicranopalpus ramosus (Opiliones, Phalangiidae), nieuw voor de Belgische fauna. Nieuwsbriefvan de Belgische Arachnologische Vereniging 10: 11-13.

Spider and Harvestman Recording Scheme 2010-2016. British Arachnological Society. Available at http://srs.britishspiders.org.uk (10 Oct 2016).

STARĘGA W. 1973. Bemerkungen über einige westpaläarktische Weberknechte (Opiliones. Revision der Phalangiidae, II. Annales Zoologici 30: 361-373.

TOFT S. \& HANSEN M.D.D. 2011. Gaffelmejerens Dicranopalpus ramosus lyninvasion i Danmark. Flora og Fauna 117: 47-51.

WiJnHOVEN H. 2009. De Nederlandse hooiwagens (Opiliones). Nederlandse Faunistische Mededelingen, Supplement, 5-118.

WiJnhoven H. 2013. Sensory structures and sexual dimorphism in the harvestman Dicranopalpus ramosus (Arachnida: Opiliones). Arachnologische Mitteilungen 46: 27-46.

Wijnhoven H. \& PRIETO C.E. 2015. Dicranopalpus caudatus Dresco, 1948: Not a synonym of Dicranopalpus ramosus (Simon, 1909) but a valid species after all (Arachnida, Opiliones). Revista Ibérica de Aracnología 26: $25-34$.

\section{STRESZCZENIE}

\section{[Pierwsze stwierdzenie ekspansywnego gatunku kosarza Dicranopalpus ramosus (Simon, 1909) (Arachnida: Opiliones) w Polsce]}

Dicranopalpus ramosus jest kosarzem, pochodzącym z południowozachodniej części Basenu Morza Śródziemnego, który w ostatnich dekadach XX i na początku XXI wieku rozprzestrzenił się na znacznych obszarach Europy Zachodniej. W pracy autorzy przedstawili informacje o odkryciu stanowiska D. ramosus Dąbrówce niedaleko Poznania. Stwierdzona populacja jest oddalona o ponad $400 \mathrm{~km}$ od najbliższych znanych stanowisk tego gatunku na terenie Niemiec i jest najdalej na wschód wysuniętą w obrębie zasięgu tego kosarza. Zebrane okazy i obserwacje sugerują, że Dicranopalpus ramosus jest na stwierdzonym stanowisku gatunkiem już zadomowionym. Wprawdzie nie odszukano dalszych stanowisk $D$. ramosus w Polsce, ale należy spodziewać się, że proces ekspansji tego gatunku będzie postępował. 